\title{
Performance and display at the first meeting of the British Archaeological Association, Canterbury, 1844
}

Gabriel Moshenska

\begin{abstract}
The congress of the British Archaeological Association in Canterbury in September 1844 was the first archaeological conference in Britain. This paper examines the visual practices of performance and display incorporated within the congress, focusing on three events: a trip to watch a barrow excavation; a visit to the Faussett collection of antiquities; and an unrolling of an Egyptian mummy. Through an analysis of these events the paper examines the ways in which members of the nascent British archaeological community in the early Victorian era learned how to observe archaeology within the correct social, intellectual and spatial frames.
\end{abstract}

\section{Keywords}

History of archaeology; public archaeology; public understanding of science; visual culture.

\section{Introduction}

In September of 1844 the British Archaeological Association held its first annual congress, a weeklong event in and around the city of Canterbury that allowed the members of the nascent society to meet, present their work and take part in scholarly and social activities. The congress remains a landmark in the history of British archaeology and within Victorian intellectual history more widely, marking a period of fast-growing popular interest in archaeology and antiquity that saw the formation of numerous regional and national learned societies and printing clubs (Levine 1986; Morrell and Thackray 1981). The Canterbury congress of the British Archaeological Association (hereafter BAA) was by most accounts a resounding success and a source of great excitement and entertainment for the archaeological attendees and residents of Canterbury, with an invigorating programme of talks, demonstrations, excursions and dances. However, it was also notable for the bitter divisions that it generated and exposed within the archaeological community, leading in the aftermath of the event to an acrimonious split in the BAA and the foundation of the rival Archaeological Institute, now the Royal Archaeological Institute (Briggs 2009; Wetherall 1994).

The programme of talks, excursions and demonstrations, based to a considerable extent on the meetings of the British Association for the Advancement of Science and the Sociéte française d'archéologie, set an enduring pattern for archaeological congresses as Ashbee notes:

The conference procedures, so effective in Canterbury, became an annual undertaking ... Across the years it has continued and today almost all societies, for example the Prehistoric and the Mediaeval, besides various county organisations, gather and follow the format that emerged in Canterbury and stimulated their forebears. (Ashbee 2006, 342)

My primary interest in this recurrent format for scholarly congresses lies in the visual aspects of display, performance and participation and in particular the role of audiences and the practice of eye-witnessing in disciplinary self-fashioning. This builds on my earlier work on the function of public audiences and eyewitnesses at excavations (Moshenska 2009; Moshenska 
and Schadla-Hall 2011) and the nature of 'the archaeological gaze' (Moshenska 2013). These in turn form part of a wider literature on visual cultures in the history of archaeology including the work of Thornton (2015) on exhibitions and Sheppard (2012) on public spectacle. There is also a rich related field of study in the creation and uses of images in archaeology, based on a recognition of their epistemic power (e.g Bradley 1997, Tilley et al. 2000, and more recently Perry 2009). In studies of the social lives of archaeological performances and scientific spectacles in general it is clear that the consumption of these intellectual commodities are understood, at least in part, through their claimed or anticipated effects upon their audiences (Morus 2006; Schaffer 1983). Popular science in the nineteenth century was concerned not only with discovery and innovation, but also with the creation of audiences for science of the correct social class and sufficiently knowledgeable as to lend authority to the findings, as Morus notes: 'When visitors to late eighteenth- or early nineteenth-century exhibitions saw science on show they were, in a sense, being taught how to see science' $(2006,109-10)$.

In this paper I want to examine some of the visual and performative dimensions of the BAA's Canterbury congress and their putative effects on those who observed them. To this end I will consider three events in particular: the day-trip to watch the excavation of several barrows at Breach Down and elsewhere; the visit to the Faussett collection of antiquities at Heppington; and the unrolling of an Egyptian mummy in a theatre in Canterbury. Previous studies of these events have focused on a variety of aspects: Rowley-Conwy (2007) and Briggs (2009) considered the organisational background to the congress; Rhodes (1990) considers them as part of the history of the Faussett collection; and Briggs (2011) placed them within the history of archaeological excavation.

\section{The British Archaeological Association}

The British Archaeological Association was founded in 1843 by a London-based group led by the pharmacist Charles Roach Smith and the writer and editor Thomas Wright. The 1830s and 1840s saw the emergence of numerous learned societies in the sciences, arts, religion, architecture and other fields, which Levine (1986) has argued bridged a gap between the emergence of an intellectually active urban middle class and the expansion of British universities in the later part of the nineteenth century.

The British Archaeological Association had its roots in the Society of Antiquaries of London, at that time a rather dusty and hidebound institution which (like the British Museum of the time) had little or no interest in non-classical antiquities including British historical or prehistoric archaeology. The Numismatic Society had formed several years before out of frustration at the Antiquaries' refusal to allow the formation of a formal numismatic interest group, and the BAA can be seen in the same light (Wetherall 1994). At the same time, there are interesting parallels with the formation of the British Association for the Advancement of Science a decade earlier, sparked by similar frustrations with the Royal Society. Importantly, while membership of the Society of Antiquaries and the Royal Society was by election, membership of the BAA and the BAAS was by subscription, and was in theory open to anybody.

It is worth noting the role of social class in the BAA. The most active members of the early BAA were metropolitan middle class men: Roach Smith and Wright, but also the playwright J.R. Planché and the surgeon Thomas Pettigrew. Levine notes that both Roach Smith and Wright experienced resistance and ill-treatment in their membership of the Society of Antiquaries, including a letter to the secretary opposing Roach Smith's election on the grounds that he 'was not a fit and proper person to be elected; but that I was in business' (Levine 1986, 21). These middle class businessmen and professionals made up roughly half 
of the Central Committee of the BAA at its foundation and were the driving force behind the congress in Canterbury. The other half were gentlemen of leisure and aristocrats, and the president was the wealthy and enthusiastic antiquarian Lord Albert Conyngham who had served as MP for Canterbury for several years and resided at Bourne Park close to the city: this played no small part in selecting the location for the BAA's inaugural congress (Wetherall 1994).

\section{Planning the congress}

One of the founders of the BAA was the physician and antiquary William Bromet, who brought to the Association his knowledge of and connections with the French antiquarian community, whose Société française d'archéologie had held its annual Congrès Archéologique in a variety of different cities since its foundation in 1834. In early 1844, at the suggestion of Roach Smith and Wright, Bromet sketched an outline for a national congress of the new BAA. His notes entitled 'Suggestions for the "getting up" of a meeting of the British Archaeological Assocn. during this Summer at Canterbury' and dated 8 May 1844 are included in a scrapbook of documents, tickets, newspaper cuttings and images collected by Roach Smith and housed in the library of the Society of Antiquaries (Roach Smith nd.). They include a number of suggestions including

That Lord Albert Conyngham be requested to confer with the Dean of Canterbury and the Chairman of the Bench of Magistrates for East Kent upon this subject: and with the mayor of Canterbury as to the accommodation of the Association during its sojourn at Canterbury there.

$\ldots$

That to effect their researches conveniently, to the members, such gentlemen who may assemble together at Canterbury be invited to form themselves into sections or sub-committees for the separate visitation (in such sections) of those monuments as may especially illustrate their previous course of study.

On the basis of this proposal a circular was distributed amongst the membership of the BAA soliciting papers and ticket sales. A draft programme was drawn up based on four separate sections: Primeval Antiquities; Medieval Antiquities; Architecture; and History. Arrangements were made with the mayor and other notables of Canterbury, and block bookings were made at hotels and inns, although the provision of sufficient beds and in particular meals remained problematic throughout the congress. Around 200 tickets were sold at 1 Guinea each, entitling the bearer to bring a lady, and including free access to the Cathedral: three tickets were sold to women. From the start most of the gentlemen and aristocrats on the Central Committee of the BAA opposed the congress, stating that it was variously too provincial, likely to be an embarrassing failure, too commercial, and vulgar. They and their supporters did not attend the Congress: Albert Way, one of the principal co-founders of the Association and the leader of the dissenting faction, was absent due to illness, with some suspecting that this may have been a ruse (Dunkin 1845; Roach Smith 1883; Wetherall 1994)

\section{The congress}

The event itself started badly on Monday 9 September with a thunderingly boring and barely audible opening paper by Sir William Betham and a chaotic first session (Figure 1). Throughout the remainder of the week the organisation of the programme and the mood of the attendees was much improved: each of the four sections held its own meetings to hear papers, while the whole association met for plenary sessions, excursions and evening entertainment (Roach Smith 1883; nd.). The Primeval section heard papers on Caesar's 
landing place in Kent, and on Egyptian and Roman antiquities. The Medieval section had papers on church wall paintings and ecclesiastical embroideries, the Architectural section got a very popular paper on Canterbury Cathedral, and the Historical section heard reports on local manuscript collections and archives. Details of the programme are recorded in the volumes published soon after the congress by Dunkin (1845); Wright (1845); and most recently by Ashbee (2006).

Alongside the talks there were a series of collective excursions and other events on alternate days as well as smaller visits for the different sections, for example to the local archives or the Cathedral. Amongst these less formal events were a number of 'conversaziones'. These were a popular form of scholarly social gathering in Victorian Britain held in hired halls or private homes for learned men and sometimes women to meet and converse, often focusing on objects, artworks, artefacts, scientific specimens or other displays laid out for their perusal. Alberti has characterised conversaziones as 'ephemeral and light-hearted evening activities', while noting their role in 'the promulgation of a culturally sophisticated urban middle-class identity in the later nineteenth century' (Alberti 2003, 208-9). The analysis of conversaziones offers insights into the visual cultures of Victorian science in general and the Canterbury congress in particular and is discussed further below.

\section{The excavation on Breach Down}

The first event on the programme that I will examine is the excursion to watch the excavation of several Anglo-Saxon barrows on the estate of Lord Albert Conyngham.

TUESDAY, Sept. $10^{\text {th }}, 1844$.

Lord Albert Conyngham will meet the Members and Subscribers to the Archaeological Society at Ten o'clock in the forenoon at BREACH DOWNS, near Barham, 8 miles from Canterbury, where a few Tumuli will have been previously opened for investigation. The party will then return to Bourne, and after partaking of some Refreshments, will examine some Tumuli in BOURNE PADDOCK. (In Roach Smith nd., 83)

The excavations took place in two areas, both of them previously explored and subject of several excavations, and therefore known to be productive of artefacts. This expedition was recorded in several of the published reports of the congress, with a more finely-detailed archaeological account of the findings by Dunkin and a rather briefer one by Wright:

Under his Lordship's supervision, a number of these barrows ... were excavated to within about a foot of the bottom, before the arrival of the visitors, in order that the deposits might be uncovered in their presence ... The archaeologists assembled at Breach Down, on Tuesday, the $10^{\text {th }}$ of September, between nine and ten o'clock, conveyances having been engaged in Canterbury for the occasion by the local committee, and eight barrows were successively opened for their inspection. The only interruption arose from a heavy shower of rain, which was so far from damping the zeal of the visitors, that many, both ladies and gentlemen, raised their umbrellas (if they had any), and stood patiently looking at the operations of the excavators. (Wright 1845, 6)

This report is significant in a number of respects, not least in the distinction between 'excavators' who dig and 'archaeologists' who watch them work: Dunkin also notes the significance of the event as an act of archaeological eye-witnessing (and see Moshenska 2013). However elsewhere Dunkin $(1845,97-8)$ refers to an attempted practical joke played 
upon 'Lord A. Conyngham's man "Charles," who was the operator in these barrow diggings', praising his skill and knowledge as well as the enthusiastic interest of the 'juvenile peasantry ... as closely and as eagerly poring after relics, as any Archaeologist present' (Dunkin 1845, 98). Dunkin ponders the impact of witnessing the excavation on these young people, imagining that they and their descendants might retain an appreciation of the value of archaeology.

The excavations revealed burials including a child interred with beads and 'toys', and a 'hunter' accompanied by a spear and shield (Wright 1845, 7). The physician William Vesalius Pettigrew provided analyses of the teeth and bones, comparing the tooth-wear of the late Anglo-Saxons to that of soldiers killed in the Wars of the Roses and others in his vast skull collection, and suggesting on that basis a diet based on dried peas and beans (Dunkin 1845, 105). One female skeleton was found with a spearhead which caused some interest, but Dr Pettigrew (whose father Thomas performed the mummy unrolling discussed below) was most interested in the absence of hair in the burials, asserting rather bizarrely that hair outlasts all other human tissues including bone in burial contexts, and that therefore the people in question were most likely shaved after death. The performance of excavation was described by Roach Smith as 'an attractive and scientific feature in the week's proceedings' (1883, 9), and certainly those in attendance seem to have enjoyed it enormously (Figure 2).

The barrow excavation with its careful stage-managing and preparation of the sites to showcase the productive final stage of the excavation follows a pattern established by public experimental scientists such as Michael Faraday, whose well-known demonstrations of electrical and other phenomena in his Friday evening discourses were always painstakingly rehearsed and prepared to illustrate particular scientific principles to his audiences (James 2010).

\section{The visit to the Faussett collection}

One of the most active early barrow diggers in the Canterbury area was the antiquarian Bryan Faussett. In his memoirs, published long after his death, he described how in July 1771 he set out to excavate a group of nine round barrows near Canterbury. He and his workmen arrived at the site early in the morning and worked at a feverish pace because, as he noted,

I know myself liable to be pestered with a numerous set of troublesome spectators ... So setting ourselves immediately to the business, we finished our work in little more than two hours; during this time, it being so early in the day, we had very little or no interruption, either from the curiosity or impertinence of passengers, or other idle spectators, the teazingness and plague of whose ill-timed attendance in business of this sort, is not to be conceived but by those who, like myself, have had the disagreeable experience of it. (Faussett 1856, 97)

It might seem as though Faussett would have disapproved of the expedition laid on for the BAA many years later and certainly he would not have shared Dunkin's tolerance of the 'juvenile peasantry', but perhaps he might have welcomed the interest of a more educated and socially elevated audience. Faussett excavated at least six hundred barrows in Kent, the majority of them Anglo-Saxon: from these excavations he accumulated a vast and valuable collection of Anglo-Saxon antiquities of various kinds. Seventy years after Faussett's death his collection came to the attention of Charles Roach Smith, who visited the Faussett family house in Heppington, Kent on a number of occasions to study the antiquities collection together with Faussett's grandson (MacGregor 1998). The collection included daggers, axes, 
spears, beads of amber, glass and amethyst, belt buckles, vessels of pottery and glass, brooches, keys and so on. As Roach Smith recalled years later:

It was at my request, and under a regulation suggested by me, that the British Archaeological Association, at its first public meeting, was received at Heppington, and permitted access to antiquarian riches. (Roach Smith in Faussett 1856, iv)

By this time many of the members of the BAA were engaged in research into Anglo-Saxon archaeology, not least the association's president Lord Conyngham, and the visit caused great excitement. Roach Smith's reference to a 'regulation' for visiting the collection is notable, as at the time there was no standard pattern for the display of a private collection to a very large visiting group, as opposed to an individual connoisseur, and the 'treasure room' at Heppington was far too small to admit the BAA's entire party. In the event, as Roach Smith describes it:

I arranged that the small room, in which the precious collections were kept, should be visited in detachments under my own guidance, and that then the visitors should be conducted to the hall for refreshments; and I had police in attendance without.

(Roach Smith 1883, 10)

The presence of the police might appear curious, given the nature of the event: certainly it was common enough at the time for people to host conversaziones in their homes where invited guests might bring antiquities, manuscripts, artworks or books as conversation pieces, without fear of their being stolen. The presence of the 'police' was primarily at least for security: it was a relatively common practice in museums of the period for managing crowds and maintaining order. Nonetheless the descent of several hundred enthusiastic scholarly visitors upon one small country house was without precedent, hence Roach Smith's decision to manage the trip so vigilantly. By all accounts the visit was a great success: the BAA members enjoyed themselves enormously, several called it the highlight of the congress, and confirmed Roach Smith's views on the importance and financial value of the collection. As Roach Smith $(1883,10-11)$ noted the visit also led to the publication and subsequent purchase of the collection by Joseph Mayer after the British Museum declined the opportunity.

\section{Unrolling the mummy}

On Friday $13^{\text {th }}$ of September 1844 at 8 o'clock in the evening, at the close of the congress, Thomas Pettigrew stood before an audience of several hundred people gathered in a theatre in Canterbury and began to unroll the linen bandages of an Egyptian mummy. Working with a knife and chisel and assisted by his son William Vesalius, Pettigrew removed the layers of cloth and bitumen until the body of the mummy could be seen through the bandages and the face was completely revealed. According to a report from the time:

At eight o'clock the theatre presented a gay appearance, being well filled with a most respectable audience; the leading families of the neighbourhood were present. All the boxes were filled" ... "and the most intense interest prevailed throughout these altogether novel proceedings." ... "the stage decorations were got up with great care, Mr. Pettigrew and the mummy being in the centre, supported on either side by antiquarians tastefully arranged so as to give full effect to this imposing scene". There was first a lecture by T.J. Pettigrew on mummies generally, which lasted an hour, and then Pettigrew, assisted by his son, Dr. W.V. Pettigrew, began the unrolling ... The greatest interest was evinced by spectators, "and from time to time pieces of the 
bandages were handed to the ladies in the boxes", although the cloth "had a peculiar and disagreeable smell". "The dust pervaded the atmosphere and was inhaled by all persons near." ... After an hour and a half "the mummy, which proved to be that of a young man, was raised to its feet, and presented to the company, and was received with enthusiastic applause". (Quoted in Dawson 1934, 179-80)

The unrolling which had begun at eight did not finish until eleven, whereupon a number of those present retired to the nearby assembly rooms to dance, as reported by the Kent Herald under the wry title THE ARCHAEOLOGICAL POLKA:

"Julia" says that after contemplating "the horrible mummy" for so many hours, and hearing so much of sepulchres, dead bodies, and bones, she could compare the Polka, which immediately followed, with Holbein's Dance of Death. (In Roach Smith nd., 117)

The set design is significant: Pettigrew's unrollings were commonly performed before a backdrop of banners printed with Egyptian reliefs and hieroglyphic texts (Moshenska 2014). Painted and gilded mummy cases added lustre to the events alongside tables of Egyptian artefacts including amulets discovered in the mummy wrappings during previous investigations. The intense interest and enthusiasm ascribed to the audience in the written account cannot be explained by the novelty of the performance alone: by 1844 mummy unrollings were well-known even outside larger cities. Like the barrow excavation there was a degree of uncertainty in a mummy unrolling: it was frequently unclear at the outset whether or not the mummy would be preserved beyond a mere skeleton, or whether it would be possible to adequately expose the body through the removal of the bandages. At the BAA congress the mummy proved to have been well sealed within a hard, bituminous layer, hence the threehour-long process to expose its face through the carapace (Ashbee 2006, 338).

The uncertain outcome formed part of the wider fascination for the audience at a mummy unrolling, alongside the faintly prurient interest in seeing a priestess or princess stripped and displayed to the public. The Kent Herald reported tongue-in-cheek that:

"Osiris," who is in the secret, writes us that he hears the betting at the sporting houses in Canterbury is ten to seven in favour of the Mummy when unrolled turning out to be a female. Curiosity is on tip-toe as to the result. (In Roach Smith nd., 105)

Even at the Canterbury congress the mummy unrolling was an odd event, with little other Egyptological material on the programme aside from Pettigrew's presentation of a paper by Sir John Gardner Wilkinson on a hieroglyphic inscription (Dunkin 1845, 344). What was its purpose on the programme? Pettigrew was by this time popularly known as 'Mummy' Pettigrew due to his having unrolling a very large number, often in front of distinguished and scholarly audiences, and the unrolling at the congress was perhaps both his own 'party piece' and a guaranteed popular entertainment at the end of the weeklong event both for the attendees and for the people of Canterbury. The place of the spectators and their responses to the performance are of particular value in elucidating the nature and significance of the event: it is clear from the description that the unrolling was not merely a visual spectacle but a multi-sensory experience for those present: the mummy was seen, the dust smelt and tasted, the bandages smelt and touched. 


\section{The aftermath of the congress}

In the period following the congress the tensions that had preceded it continued to provoke divisions amongst the members of the BAA. The members of the central committee who had organised and coordinated the event felt let down by those who had stayed away, while the opposing faction (having been proven incorrect in their predictions of failure) described the event as an embarrassment, alluding to the excursions and demonstrations as 'cockneyisms' or vulgar popularizations (Wetherall 1994, 14). In turn, the supporters of the congress were no less vehement: Dunkin's introduction to his book-length account of the congress contains vitriolic denunciations of 'drones in the Archaeological hive ... the timid and insincere' (1845, v).

In the months following the congress the objections to the congress focused on Thomas Wright's Archaeological Album (1845), an entertaining and well-illustrated report on the event, which was accused rather spuriously of harming the sales of the BAA's own journal. The Committee split in two, each part rather confusingly declaring itself to be the true BAA. In due course the more socially elite faction that had boycotted the congress, and which retained most of the aristocratic and clerical members, renamed itself the Archaeological Institute, later the Royal Archaeological Institute. The minutiae of this unpleasant period which reflects poorly on virtually all involved and produced some appalling light verse are detailed in Wetherall (1994).

\section{Discussion}

In putting on excursions, demonstrations, spectacles and displays such as those described above, alongside inter alia visits to archives, churches and Canterbury Cathedral, the BAA were aligning themselves with the cutting edge of popular science at a time when the formats for congresses and conferences were not yet set in stone. The model of the conversazione discussed earlier offers insights into the interplay of performance, display, audience and reception in nineteenth-century bourgeois intellectual culture, and in particular the active rather than passive role of what might otherwise be considered the 'public'. As Alberti notes:

The conversazione clearly demonstrates that Victorian public were not simply passive audiences for an active, élite scientific community. The middle classes attended these events not only to see the spectacle, but also to be seen themselves, to be part of the show. (Alberti 2003, 209)

Alberti $(2003,223)$ links the phenomenon of the conversazione to two increasingly significant themes in the historiography of Victorian science, noting both the public's increasingly active, participative approach to the creation and consumption of scientific knowledge and the degree to which these activities were intricately interconnected with Victorian culture more widely. He concludes that

The audiences for science were varied, but all were active, experiencing natural knowledge through sight, speech, sound and touch. At the conversazione, the very notion of 'audience' is complicated, as so many were involved in the exhibitions and displays, and those present were themselves part of the spectacle. (Alberti 2003, 224)

The programme of performances and displays at the BAA's Canterbury congress show the nascent archaeological community drawing upon the conceptual and communicative toolkits of Victorian scientific culture. The varying reception of these new forms, from ecstasy to 
outrage, is perhaps indicative of their novelty and their association with the fast-growing middle-class intellectual society in this period, characterised by widespread membership of scientific, ecclesiological, antiquarian and other clubs and societies (Wetherall 1998). The members of the British Archaeological Association left Canterbury with their identities as archaeologists reinforced by incorporation into social and intellectual networks and through the enactment of archaeological practices of observation and eye-witnessing in the theatre, the lecture hall, the museum and the field.

\section{References}

Alberti, S. 2003. "Conversaziones and the Experience of Science in Victorian England." Journal of Victorian Culture 8: 208-30.

Ashbee, P. 2006. “Canterbury's 1844 Archaeological Congress." Archaeologia Cantiana 126: 331-43.

Bradley, R. 1997. 'To see is to have seen': craft traditions in British field archaeology.' In The Cultural Life of Images: Visual Representations in Archaeology, edited by B.L. Molyneaux, 62-72. London: Routledge.

Briggs, C. S. 2009. "Some reflections on the Archaeological Institute's Oxford Congress in 1850." Archaeological Journal 166: 210-36.

Briggs, C. S. 2011. "Some notable British excavations before 1900". In Great Excavations: Shaping the Archaeological Profession, edited by J. Schofield, 12-24. Oxford: Oxbow.

Dawson, W. R. 1934. "Pettigrew's demonstrations upon mummies: a chapter in the history of Egyptology." Journal of Egyptian Archaeology 20: 170-82.

Dunkin, A. J. 1845. A Report on the Proceedings of the British Archaeological Association at the First General Meeting held at Canterbury in the Month of September, 1844. London: John Russell Smith.

Faussett, B. 1856. Inventorium Sepulchrale by the Rev. Bryan Faussett; edited, from the original manuscript in the possession of Joseph Mayer; with notes and introduction, by Charles Roach Smith. London: T. Richards.

James, F. 2010. Michael Faraday: A Very Short Introduction. Oxford: Oxford University Press.

Levine, P. 1986. The Amateur and the Professional: Antiquarians, Historians and Archaeologists in Victorian England 1838-1886. Cambridge: Cambridge University Press.

MacGregor, A. 1998. "Antiquity Inventoried: Museums and 'National Antiquities' in the Mid Nineteenth Century." In The Study of the Past in the Victorian Age, edited by V. Brand, 12537. Oxford: Oxbow.

Morrell, J. and A. Thackray. 1981. Gentlemen of Science: Early Years of the British Association for the Advancement of Science. Oxford: Oxford University Press.

Morus, I. R. 2006. "Seeing and believing science." Isis 97(1): 101-110. 
Moshenska, G. 2014. "Unrolling Egyptian mummies in nineteenth-century Britain." British Journal for the History of Science 47(3): 451-77.

Moshenska, G. 2013. "The Archaeological Gaze." In Reclaiming Archaeology: Beyond the Tropes of Modernity, edited by A. González-Ruibal, 211-9. Abingdon: Routledge.

Moshenska, G. 2009. "Beyond the viewing platform: excavations and audiences." Archaeological Review from Cambridge 24(1): 39-53.

Moshenska, G. and T. Schadla-Hall. 2011. "Mortimer Wheeler's theatre of the past." Public Archaeology 10(1): 46-55.

Perry, S. 2009. "Fractured media: challenging the dimensions of archaeology's typical visual modes of engagement." Archaeologies 5(3): 389-415.

Rhodes, M., 1990. "Faussett Rediscovered: Charles Roach Smith, Joseph Mayer, and the Publication of Inventorium Sepulchrale." In Anglo-Saxon Cemeteries: A Reappraisal, edited by E. Southworth, 25-64. Stroud: Alan Sutton.

Roach Smith, C. 1883. Retrospections Social and Archaeological Vol. 1. London: Whiting and Co.

Roach Smith, C. nd. British Archaeological Association. First Congress. 1844. Society of Antiquaries of London.

Rowley-Conwy, P. 2007. From Genesis to Prehistory: the Archaeological Three Age System and its Contested Reception in Denmark, Britain, and Ireland. Oxford: Oxford University Press.

Schaffer, S. 1983. "Natural philosophy and public spectacle in the eighteenth century." History of Science 21(1): 1-43.

Sheppard, K. L. 2012. "Between spectacle and science: Margaret Murray and the Tomb of the Two Brothers." Science in Context 25(4): 525-549.

Thornton, A. 2015. Exhibition Season: Annual Archaeological Exhibitions in London, 1880s1930s. Bulletin of the History of Archaeology 25(1).

Tilley, C., Hamilton, S., and Bender, B. 2000. "Art and the Re-Presentation of the Past." Journal of the Royal Anthropological Institute 6(1): 35-62.

Wetherall, D. M. 1994. "From Canterbury to Winchester: The Foundation of the Institute". In Building on the Past: Papers Celebrating 150 Years of the Royal Archaeological Institute, edited by Blaise Vyner, 8-21. London: Royal Archaeological Institute.

Wetherall, D. M. 1998. "The Growth of Archaeological Societies" In The Study of the Past in the Victorian Age, edited by V. Brand, 21-34. Oxford: Oxbow.

Wright, T. 1845. Archaeological Album, or Museum of National Antiquities, London: Chapman \& Hall. 


\section{Figures}

Figure 1: The congress underway in the town hall, Canterbury. From Dunkin 1845, 22.

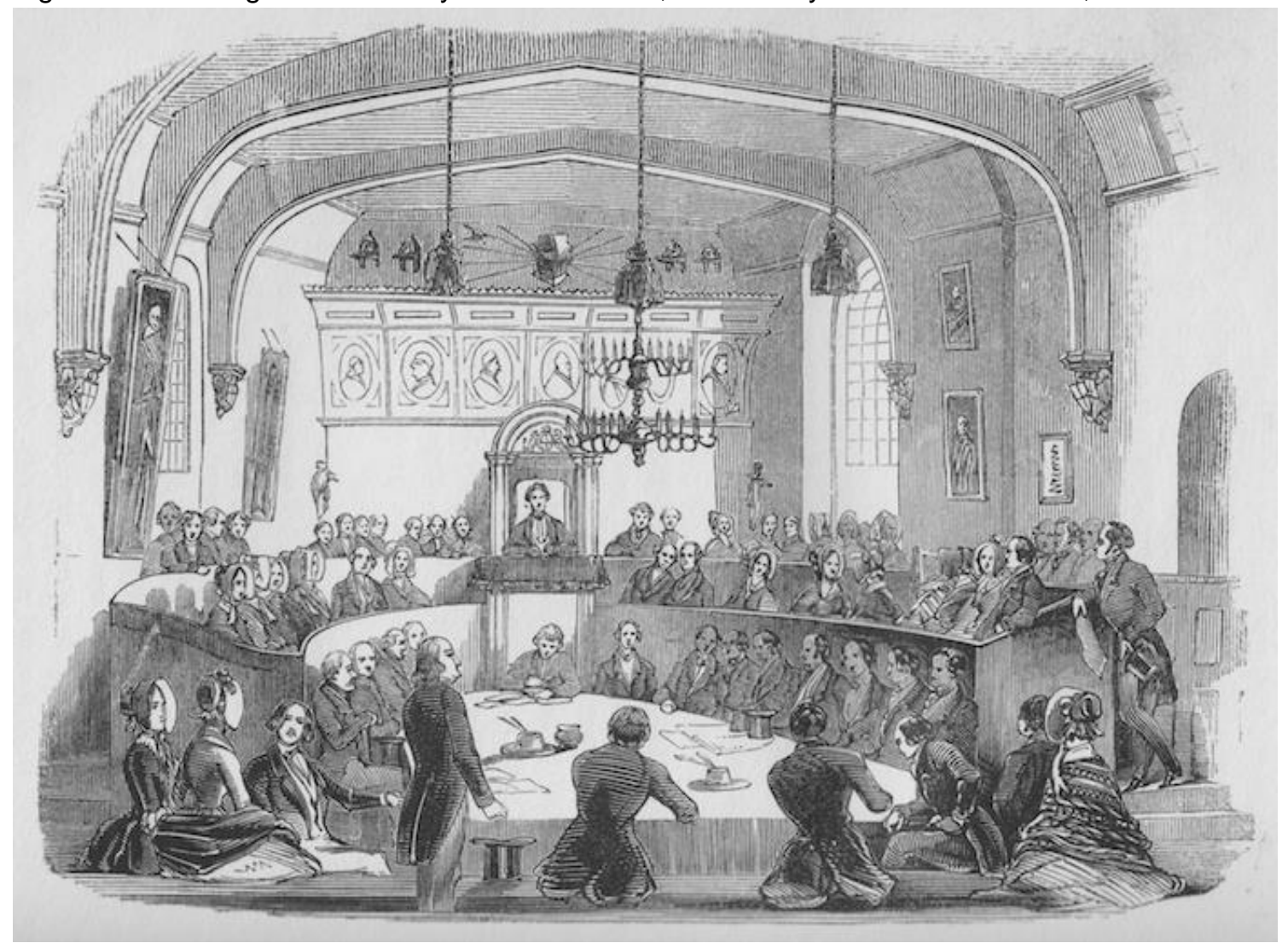

Figure 2: The excavation at Breach Down. From Dunkin 1845, 93.

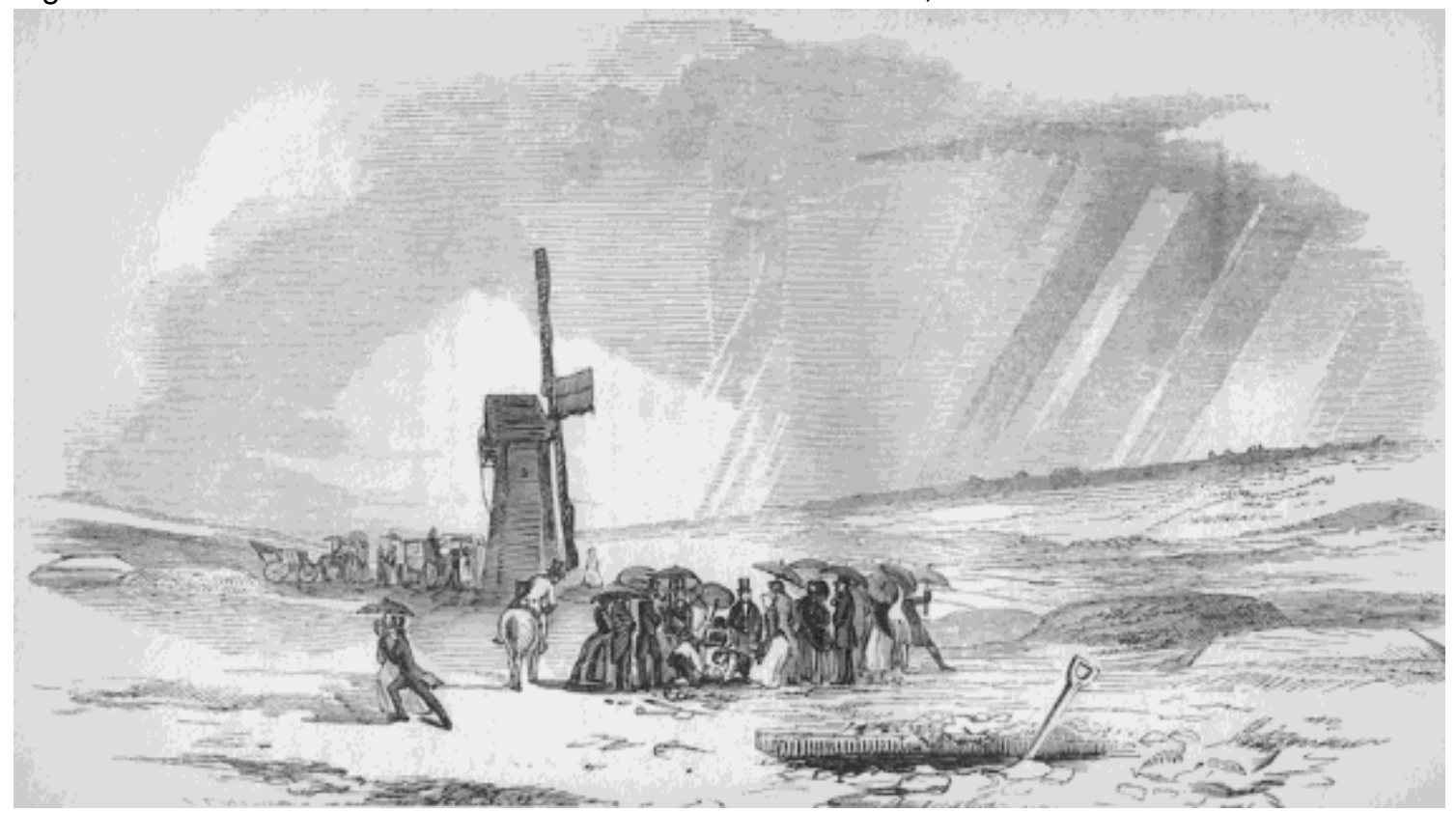

\section{Acknowledgements}

This paper builds on research carried out during an Early Career Research Fellowship funded by the Leverhulme Trust, for which I am extremely grateful. I am also indebted to the 
attendees of the Histories of Archaeology Research Network workshop on Performance and Display in the History of Archaeology for their comments on an earlier draft, and in particular to my co-organisers of this event, Clare Lewis and Amara Thornton. Finally, I am grateful to the editors and referees for their very constructive responses to an earlier version of this paper. 